\title{
PROMOTING STUDENT ENGAGEMENT THROUGH OUTCOMES BASED EDUCATION IN AN EAL ENVIRONMENT
}

\author{
ROBERT CRAIG 1 \\ Petroleum Institute (UAE)
}

\section{RESUMEN}

La educación basada en resultados de aprendizaje es un enfoque que ha sido promovido y adoptado en distintos sistemas educativos de todo el mundo desde el comienzo de la década de 1990. Se han adaptado numerosos programas de manera exitosa a lo largo del tiempo, mientras que otros han quedado obsoletos por distintos motivos, entre los que se pueden señalar las interpretaciones, cuestiones relacionadas con la evaluación, el aumento de la carga de trabajo del profesorado y quizá asuntos más filosóficos relacionados con la naturaleza del aprendizaje. Sin embargo, mientras que puede haber un caso que se haya preparado para que el aprendizaje holístico se pierda mediante un enfoque rígido y atómico, hay un rango de beneficios indudable. Uno de ellos es que un programa basado en resultados bien diseñado puede mejorar el compromiso del alumnado debido a la naturaleza de las actividades y tareas requeridas para demostrar su rendimiento. Los procesos basados en resultados también son también uno de los requisitos de los órganos de acreditación para demostrar responsabilidad, así como también para establecer indicadores claros de lo que los estudiantes serán capaces de hacer tras determinadas fases de aprendizaje, al final de un curso o tras su graduación.

Un resultado de aprendizaje de especial relevancia en los contextos del inglés como medio de instrucción (EMI) y del Aprendizaje Integrado de Contenidos y Lenguas Extranjeras (AICLE) es el requisito de demostrar la capacidad de comunicarse de manera eficaz. En la formación universitaria, el objetivo de este resultado particular tiene dos características principales: por una parte, facilitar el desarrollo cognitivo mediante la adquisición, asimilación y articulación del conocimiento; y por otra es facilitar a los graduados a entrar en el ámbito laboral y ser aceptados como miembros de una comunidad discursiva de una disciplina. Con tal, la responsabilidad de cada programa consiste en asegurar que los pasos que se dan para facilitar las oportunidades, y no solo mediante el conocimiento anticipado de competencias lingüísticas en cursos de idiomas previos.

Este artículo pone de relieve un enfoque basado en resultados aplicado a una asignatura optativa de Humanidades para estudiantes de inglés como lengua adicional en una escuela de ingeniería de Oriente Próximo. El objetivo del diseño es introducir un requisito lingüístico relevante mientras que se atrae a los estudiantes en un rango de canales de aprendizaje multimodales estimuladores, incidentales y explícitos.

Palabras clave: Actuación lectora, profundidad léxica, amplitud léxica.

\section{ABSTRACT}

Outcomes-based education is an approach that has been promoted, and adopted in several education systems around the world since the early 1990s. Many programs have been adapted successfully over time while others have been phased out for various reasons, including interpretations, issues with assessment, increased instructor workload and perhaps more philosophical issues concerning the nature of learning. However, while there may be a case to be made for holistic learning being lost in a rigid, atomistic approach, there is undoubtedly a range of benefits. One of these is that a well-designed outcomes-based program can help facilitate student engagement because of the nature of the activities and tasks required to demonstrate performance. An outcomes-based process is also one of the

\footnotetext{
1 Email: rcraig@pi.ac.ae
} 
requirements of most accrediting bodies in order to demonstrate accountability, and for setting clear statements of what students will be able to do after particular phases of learning, by the end of a course or upon graduation.

A one particular learning outcome of relevance to EMI (English as Medium of Instruction) and (CLIL (Content and Language Integrated Learning) environment is the requirement to demonstrate the ability to communicate effectively. In undergraduate education, the objective of this particular outcome has two main features; one is to facilitate cognitive development through the acquisition, internalization and articulation of knowledge and the second is to enable graduates to enter the workplace and be accepted as members of the disciplinary discourse community. As such, the responsibility of each program is to ensure that steps are taken to provide every opportunity for this to be achieved and not just through the frontloading of language skills in earlier language courses.

This paper outlines an outcomes-based approach applied to an undergraduate Humanities elective course for EAL (English as an Additional Language) students at an engineering institute in the Middle East. The aim of the design is to embed a significant language requirement while engaging learners in a range of stimulating, incidental and explicit, multi-modal learning channels.

Key words: Learning Outcomes; Engagement; Accountability; CLIL; EAL Higher Education; Bloom's taxonomy

\section{Introduction}

Engaging undergraduate students in their learning has become a focus of higher education over the last decade or so. This is understandable as governments and institutions seek ways of developing human resources in the knowledge, skills and competencies required for participation in a knowledge-based society, and, of course, improving retention rates. Research has identified different approaches to understanding student engagement in higher education, including socio-cultural (Geyer, 2001), behavioural (Kohl, 2001), and psychological (Jimerson, Campos, and Greif, 2003) aspects which are best brought together under a more holistic perspective. Christenson and Wylie's (2012) definition of engagement is that it is "multidimensional, involving aspects of a student's emotion, behaviour and cognition" ( $p 3$ ). Research has also found that students who are engaged are far more likely to devote more time outside of class to their studies and perform better in course assessment (Tross, Harper, Osher, and Kneidinger, 2000), demonstrating significant cognitive and skill development in the process (Anaya, 1996). They are also more likely to complete their degree (Bean, 2005). While it may not be particularly surprising, studies have also shown that engagement additionally results in more positive images of self (Harper \& Quaye, 2014).

The attention given to engagement has also resulted from findings from the learning sciences and best practice which have led to rethinking learning environments so that students are provided with opportunities to work, learn and share together, and in the process build on knowledge and comprehension (Marriam and Caffarella,1991; Chau and Cheng, 2010). This shift from instruction to a paradigm more focused on learning through student-centred and inquiry-based pedagogies is believed to allow learners to become "active agents involved in constructing knowledge, refining their understanding, and learning socially through sharing with peers and teachers" (Kinkead, 2003). Research suggests that the benefits of engagement in inquiry-based learning address the competences required of professionals and equips students with a more developed appreciation of life-long learning, improved self-confidence and collaboration skills, as well as improved higher order thinking and problem solving abilities (Zhan, 2014; OECD, 2004). Chickering and Gamson's (1987) "Seven principles of good practice in undergraduate education" contributed enormously to approaches developed to address issues of student engagement, and when implemented can help to foster the "conditions that compel students to make the most of college, both inside and outside the classroom" (Harper and Quaye, 2009, p.1). 
A range of measurable outcomes is required, however, to demonstrate students' active participation in the learning process, and what knowledge, skills and competencies have been acquired and developed. An outcomes-based approach to course design is one way of helping students to become more engaged. Nilson (2010) goes as far as to say that such an approach "guarantees a high level of student engagement because the process steers you toward student- active teaching strategies" ( $p 18)$, as an outcomes-based approach is learner-centred, requiring teaching strategies which facilitate active, hands-on learning.

\section{Learning Outcomes}

Learning outcomes have been generally categorized into five domains - Psychomotor, Affective, Social, Ethical, and Cognitive (Bloom, 1956). Fink (2003), however, believes that in order to provide opportunity for a significant learning experience, a course should incorporate the following six interactive categories of learning: Foundational knowledge, Application, Integration, Human dimension, and Learning how to learn. This paper will focus on cognitive outcomes, as they are the type of learning outcome most commonly associated with higher education. In an attempt to recognize and encompass a more holistic approach to learning, I shall categorize them broadly as 'Student Learning Outcomes,' defining them as:

Comprehensive, broad statements pertinent to the knowledge, skills and aspects of competence that a learner is expected to know and be able to do by the time of graduation or completion of a program, that is, on completion of a learning process.

They are written from the student's point of view in terms of what s/he might achieve, with, of course, the proviso that appropriate academic behaviour, preparing for and attending classes, adhering to task descriptions and completing assignments, etc. is maintained. The intention is that students acquire the stated knowledge, skills and competencies as they progress through the program.

Outcomes-based education (OBE) has, however, seen considerable criticism. Berlach's 2004 paper perhaps encapsulates best the general suspicions of OBE. Among his many criticisms, he states that it is "confusing" (p.3), "jargon-impregnated" (p5), and "suffocates teachers" (p7) who "suffer from assessment overload" (p. 9), all of which paints a rather depressing picture of an approach to what Hejazi and Janzen (2011) believe is "transformational." Jenkins and Unwin (2001) list eight supportive areas; they say that OBE benefits both teachers and students in that both have a better understanding of what they will be doing during the course or class, what they might gain, and what is expected of them. As such, effective learning and teaching is more likely to take place. Teachers, they say, are able to use the stated learning outcomes as templates for developing materials, and in the selection of suitable appropriate activities for developing and assessing them.

Developing learning outcomes is a top-down process. The identification of suitable outcomes is normally driven by the mission statement of the institution, and cascades down, as shown in Fig 1 below. Program Educational Objectives, are broad statements which describe what graduates of a program are normally expected to attain within a few years after graduation, such as being effective life-long learners, demonstrating professional and ethical responsibility; embarking on a chosen career path or pursuing post-graduate study. They should align with the mission and each learning outcome should be mapped to show where student learning outcomes are developed and assessed across the curriculum. This in turn provides faculty with a clear indication of their teaching objectives and helps to identify appropriate teaching and assessment strategies. However, top-down only is unlikely to occur, as while departments are accountable for quality teaching, traditionally, most have considerable control of their particular activities; "the responsibility of teaching lies first with the faculty, any concerns about quality teaching occur at the level of the departments, where the discipline culture prevails" (Hénard, p 66). 


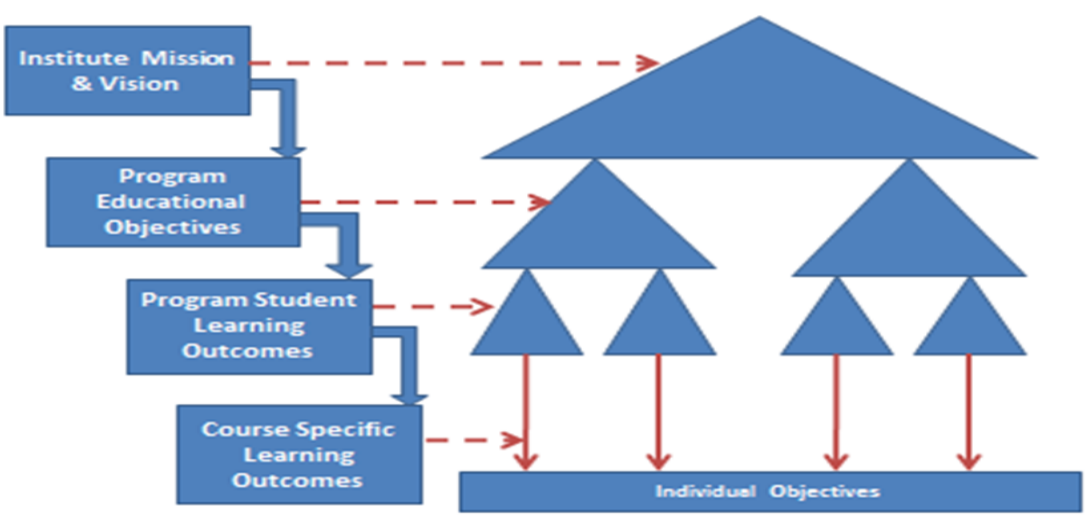

Fig. 1. Top-down development of program and course learning outcomes

Typical Program Learning Outcomes may be written, for example, in broad, non-discipline specific statements such as:

'On successful completion of the program students will possess the knowledge, skills and competencies to:

Table 1. Core Learning Outcomes

\begin{tabular}{l|l}
\hline 1 & Apply theory and methods to solving problems \\
\hline 2 & Collect, organize and apply information in a given context \\
\hline 3 & Use technology to find and/or apply information \\
\hline 4 & Collaborate successfully with others \\
\hline 5 & Communicate effectively \\
\hline 6 & Become creative and critical thinkers \\
\hline 7 & Be independent life-long learners \\
\hline
\end{tabular}

Upon completion of such a program, students will have had opportunity to participate in a range of courses developed to enhance knowledge, skills and competencies. Attainment of them involves Anderson and Krathwohl's (2000) knowledge dimensions - Factual, Conceptual, Procedural and Metacognition - and the dimensions of cognitive process - Remember, Understand, Apply, Analyse, Evaluate, and Create. One assumption is that knowledge and skills gained in courses will transfer to others. Of course, activities and tasks developed to address the above learning outcomes require that learners "assume greater responsibility and actively participate in the learning process" (Malan, 2000, p 28). This requires that learners demonstrate an understanding of that process and of how they fit into it, and involves the recognition of how knowledge is created and of how it can be accessed, evaluated and used effectively and accurately to address audience and purpose. There is also a need to understand that language development is a social activity and that it can be developed inside and outside of the classroom, independently and collaboratively. Learners, especially undergraduate students, need to plan, formulate questions, collect and organize relevant information which can be achieved through what Beichner, Deardorff and Zhang (1999) term a GOAL protocol (Gathering information, Organizing a process, Analysing a problem and Learning from their efforts). It is also evident to Malan (2000) that those 
engaged in developing and facilitating learning environments also have to consider valid and reliable assessment.

\section{Real World Tasks}

A well-designed outcomes-based program can help facilitate student engagement because of the nature of the activities and tasks required to demonstrate performance. Conventional EFL methodologies are believed to lack the "authenticity of purpose" (Coyle, Hood and Marsh, 2010, p. 5) to engage students sufficiently for them to persist in the 'authentic communication' (Dalton-Puffer, 2007, p. 3) sought after in the CLIL classroom. The interrelationship of content, cognition, communication and culture (Coyle, 2007) lends itself to an outcomes-based approach, and the paradigm shift to inquiry guided learning is one that can be scaffolded to address higher order thinking, natural communication, and metacognition.

Simulating professional, adult activity is particularly significant to young adults as they are more likely to find the approximation of professional practice engaging and more conducive to learning than lecturebased delivery (Marriam and Caffarella, 1991). CLIL provides opportunity for students to develop a range of skills including critical thinking, analysis, problem solving, teamwork, and critical reading and writing. Constructivist theories of learning (Vygotsky, 1978) show how learners construct and define their knowledge and understanding, and ZDP (Zone of of proximal development) demonstrates the importance of social interaction with peers, near peers and teachers. It also confirms the role of communication in shaping thought and learning through gathering and processing information, analysis, and synthesis. Active learning requires students to reflect on existing knowledge to develop conceptual understanding and is more likely to be facilitated through active participation and sharing problem solving with colleagues. It is particularly applicable to CLIL as it can promote language development through repeated exposure to the language of content, discussion and decision making, and the employment of higher order thinking, and as such, facilitates life-long learning. Team-based research projects, for example, with clearly defined learning outcomes, engage students in real-world communication activity, and encourage ownership of the team's work. Motivation for and buy-in to such engagement with content, via the approximation of real world, professional practice can be strong, as are language gains from both the input and output (Bransford, Brown and Conking, 2000; Beckett and Miller, 2006).

\section{Course Specific Learning Outcomes}

Developing appropriate teaching and assessment strategies from the Program Outcomes provides some freedom for those responsible for course design. A Course Learning Outcome is a comprehensive statement pertinent to the knowledge, skills and aspects of competence that a learner is expected to know and is able to do by the end of a particular course. Each Course Learning Outcome should map to one or more Program Learning Outcomes. The difference between the two is the level of specificity in describing what a student will know and be able to do at the end of the course. Normally, there are four to six Course Learning Outcomes for a given course, in order to address the core life skills shown in Table 1. Course Learning Outcomes should be made clear to students and stated on the course syllabus.

If the purpose of teaching is to facilitate learning, then the pedagogy to facilitate that learning is of the utmost importance, particularly if we want students to be able to acquire, internalize, explain, justify and articulate that learning. We cannot assume that just because teaching takes place, learning automatically occurs. It is important to remember that the pedagogy for facilitating is as important, if not more so, as the content. Harper and Quaye (2014) state that we should not expect students to take responsibility for engaging themselves. Today, educators need to create appropriate learning environments which will stimulate inquisitiveness and creativity for active engagement and learning. This means that goals involving higher order thinking skills need to be set, and strategies for achieving them implemented, particularly those that meet the expectations of Gen $Z$ who now account for almost two billion people, over a quarter of the world's population (The McCrindle Blog). Generation $Z$ expect to use the Internet and technology; they are perhaps the first true digital natives as their formative years have been spent on the 
Robert Craig

World Wide Web. As such, the use of ICT tools should be play an important role in the learning process, and outcomes developed to tap the skills students possess.

\section{Developing Course Specific Learning Outcomes}

The following example, taken from a Humanities and Social Science History elective course (for engineering students) is not sufficiently specific to show students what they will be expected to do or achieve during the course. While the course teacher may be able to provoke interest via his or her own enthusiasm and personality, the stated 'outcome' is also rather 'dry':

"By the end of the course students will have demonstrated a comprehensive and clear understanding of the origins, growth and trajectory of the oil industry in the Middle East."

The accompanying syllabus indicated only an assessment breakdown in terms of quizzes, tests, and assignments. What is needed is further exploration of the steps students would need to take in order to achieve such a demonstration, and the activities which might stimulate interest.

Anderson and Krathwohl, in a revision of Bloom's (1956) work, provide a taxonomy of hierarchical, cognitive operations (Table 2, below). While it seems obvious that students need to acquire knowledge before they can move on to higher order thinking such as analysis, application and evaluation, the scaffolding provides teachers/course designers with a framework for developing learning outcomes, material for input and assessment at suitable stages of the course.

Ideally, each outcome should be realistic in terms of achievability, reflect appropriate levels of cognition and be assessable and measurable. The objective of stating the intended outcomes is to provide a clear picture of the course, so that students know what they will learn, and how they will demonstrate their learning. More specifically, students should know what they are expected to do, what knowledge, skills and competencies they need to demonstrate their learning. The key to using the table is to first clearly state the intended outcome, framed with an action verb and noun phrase, of what a student should know (cognitive), be able to do (skills), or value (affective).

Rewriting the above example to:

"By the end of the course students will have demonstrated an ability to write a brief essay relating the stages of oil exploration and production to the development of Emirati society"

would require students to organize their response through a number of steps identified below.

The first of the knowledge dimensions refers to the Factual Knowledge $(A)$ that is required to complete the task. This includes facts, terminology, and supporting details which would demonstrate a sound understanding of the disciplinary requirements. Conceptual Knowledge $(B)$ is the term given to aspects of the discipline such as basic theories, principles and models. Procedural Knowledge (C) refers to information or knowledge that helps students to do something specific to a discipline, subject, or area of study. The last dimension, Metacognitive Knowledge (D), is concerned with reflection. In particular it is concerned with the demonstration of awareness of the cognitive processes used or applied in addressing task issues.

Table 2. Krathwohl's Taxonomy Table (Adapted from Krathwohl, 2002)

\begin{tabular}{l|c|c|c|c|c|c}
\hline Knowledge & \multicolumn{5}{|c}{ Cognitive Process Dimension } \\
\cline { 2 - 7 } Dimension & Remember & Understand & Apply & Analyze & Evaluate & Create \\
\hline A. Factual & Step 1 & & & & & Step 6 \\
\hline B. Conceptual & & Step 2 & Step 3 & Step 4 & Step 5 & \\
\hline C. Procedural & & & & & & \\
\hline D. Metacognition & & & & & & \\
\hline
\end{tabular}


Organizing and clearly stating the basic process as in the above table would probably assist the students' understanding of how to approach the task but it remains geared to a traditional, academic expectation and does not address the categories of procedure and metacognition. It also assumes high motivation levels and students in tune with a traditional, academic approach.

The example could be developed beyond the traditional demonstration of factual and conceptual knowledge to include a range of additional learning outcomes, and indications of what students might be asked to do to demonstrate attainment of them, as suggested in Table 3, below.

Table 3. Course Specific Learning Outcomes, Performance Indicators and Assessment Venues

\begin{tabular}{|c|c|c|c|c|}
\hline $\begin{array}{c}\text { LO } \\
\text { (Table 1) }\end{array}$ & $\begin{array}{l}\text { Course Specific Student } \\
\text { Learning Outcome } \\
\text { (By the end of the course } \\
\text { students will have ....) }\end{array}$ & $\begin{array}{l}\text { Importance } \\
\text { Level } \\
\text { (H-M-L) }\end{array}$ & $\begin{array}{c}\text { Performance Indicators } \\
\text { (During the course students } \\
\text { will...) }\end{array}$ & Assessment Venue \\
\hline \multirow{2}{*}{2} & \multirow{2}{*}{$\begin{array}{l}\text { collected, organized and } \\
\text { applied information related } \\
\text { to the stages of exploration }\end{array}$} & \multirow{2}{*}{$\mathrm{H}$} & $\begin{array}{l}\text { i. produce a timeline/flow } \\
\text { chart of events \& effects }\end{array}$ & $\begin{array}{l}\text { Oral/multimedia (Team) } \\
\text { Presentation of Timeline }\end{array}$ \\
\hline & & & $\begin{array}{l}\text { ii. develop questions and } \\
\text { answers related to the topic }\end{array}$ & Web-page FAQs \\
\hline \multirow[b]{2}{*}{3} & \multirow{2}{*}{$\begin{array}{l}\text { identified, accessed and } \\
\text { critically read relevant } \\
\text { materials from a variety of } \\
\text { internet-based sources }\end{array}$} & \multirow[b]{2}{*}{$\mathrm{H}$} & \multirow{2}{*}{$\begin{array}{l}\text { i. maintain an individual online } \\
\text { portfolio of annotated texts } \\
\text { and notes }\end{array}$} & Portfolio \\
\hline & & & & $\begin{array}{l}\text { Webpage links to further } \\
\text { reading \& annotated } \\
\text { bibliography }\end{array}$ \\
\hline \multirow[t]{2}{*}{4} & \multirow{2}{*}{$\begin{array}{l}\text { collaborated successfully } \\
\text { with others to achieve a } \\
\text { common goal }\end{array}$} & \multirow[t]{2}{*}{ M } & $\begin{array}{l}\text { i. cooperate and contribute } \\
\text { evenly and fairly to the team } \\
\text { goal }\end{array}$ & Peer evaluation \\
\hline & & & $\begin{array}{l}\text { ii. actively engage on } \\
\text { individual and team tasks }\end{array}$ & Instructor observation \\
\hline \multirow{3}{*}{5} & \multirow{3}{*}{$\begin{array}{l}\text { articulated an } \\
\text { understanding of how the } \\
\text { UAE oil story unfolded }\end{array}$} & \multirow{3}{*}{$\mathrm{H}$} & i. interview (and translate) & Webpage interview report \\
\hline & & & $\begin{array}{l}\text { ii. present, orally, (in a team) } \\
\text { an overview of the UAE oil } \\
\text { story }\end{array}$ & $\begin{array}{l}\text { Team presentation / short } \\
\text { video }\end{array}$ \\
\hline & & & $\begin{array}{l}\text { iii. develop, research and } \\
\text { produce a team written } \\
\text { magazine article complete }\end{array}$ & $\begin{array}{l}\text { iMagazine / webpage } \\
\text { article }\end{array}$ \\
\hline \multirow[t]{2}{*}{6} & \multirow{2}{*}{$\begin{array}{l}\text { speculated on the } \\
\text { consequences to Emirati } \\
\text { society of oil exploration } \\
\text { and production }\end{array}$} & \multirow[t]{2}{*}{ M } & $\begin{array}{l}\text { i. identify political, commercial } \\
\text { and economic factors which } \\
\text { affected the course of this }\end{array}$ & $\begin{array}{l}\text { Individual written } \\
\text { assignment }\end{array}$ \\
\hline & & & $\begin{array}{l}\text { ii. participate in class } \\
\text { discussion }\end{array}$ & $\begin{array}{l}\text { Instructor evaluation of } \\
\text { 'Contribution' }\end{array}$ \\
\hline 7 & $\begin{array}{l}\text { demonstrated an } \\
\text { awareness of, and } \\
\text { engagement in } \\
\text { independent life-long } \\
\text { learning }\end{array}$ & M & $\begin{array}{l}\text { i. evaluate own performance } \\
\text { in terms of engagement, skills } \\
\text { and knowledge development }\end{array}$ & $\begin{array}{l}\text { Reflective essay / journal } \\
\text { / blog }\end{array}$ \\
\hline
\end{tabular}

Table 3 attempts to identify six possible learning outcomes which address knowledge dimensions and the cognitive process employed. Each of these steps can be indicated on the course syllabus and schedule showing students stages, methods and products. The activities and tasks are guided by best practice and by what we know of Gen Z, a generation of learners who perform best when engaged in multi-modal learning channels. Whereas traditionally learning was restricted to the classroom, the approach outlined above is more visually engaging and can be implemented anywhere, facilitating a 'flipped' approach, if desired. The role of the teacher remains important but now as a facilitator of 
learning rather than as an imparter of knowledge. Students should be able to identify with the general topic which is localized; they understand and are able to perform the tasks which are in line with how they access and use information. Performing each chosen task would amount to a demonstration of learning, not only of content but of the language acquired to present a factual and persuasive account. Procedural and metacognitive aspects can also be added to the dimensions through class or online instruction, such as YouTube, individual and peer editing, hands-on experience of developing the web-page or other visuals, and through reflection on how well the task was performed. The incidental learning is as important as the explicit.

The importance or relevance of each course learning outcome is unlikely to be equal. This is indicated by the letters $\mathrm{H}$ (high), $\mathrm{M}$ (medium) and $\mathrm{L}$ (low). $\quad \mathrm{An}$ ' $\mathrm{H}$ ' indicates that the knowledge, skill and/or behaviour is one of the most important outcomes of the course. As such, this means that instructors should provide students with formal instruction, opportunities for practice, and formal assessment relevant to that knowledge, skill or behaviour, and assessment weighting is likely to be higher. An ' $\mathrm{M}$ ' indicates that the knowledge, skill and/or behaviour is not the most important outcome of the course but is still likely to have a considerable impact on the student's performance; in this case, instructors provide more indirect instruction, opportunities for practice, and formal assessment of that knowledge, skill or behaviour. An ' $\mathrm{L}$ ' indicates that the knowledge, skill or behaviour has only minor impact on the performance of the student. Consequently, no direct instruction or assessment of the skill is likely to done during the course; however, the course will provide opportunities for practice.

\section{Performance Indicators}

The Performance Indicators of the fourth column in Table 3, above, are specific, measurable statements which serve to identifying the performance required to demonstrate attainment of a learning outcome. They also serve to describe what students can be expected to do, learn and engage in during the course. Evidence of performance level also needs to be described, commonly on a four-point scale equivalent to terms such as 'Exemplary', 'Effective', 'Developing', and 'Ineffective,' and are usually presented in the form of a rubric. Normally, two or three indicators are used at different points on the course to assess performance on each learning outcome. Rubrics or performance descriptors serve not only for evaluation guidance but also help provide clear task descriptions for learners, and useful feedback about their strengths and weaknesses.

\section{The Continuous Assessment Process and Closing the Loop}

The top-down design enables knowledge, skills and competencies to be addressed across the curriculum, and facilitates course design which is informed by best practice. Student performance on specific outcomes can be measured by appropriate assessment venues, indicators and descriptors. The learning outcomes for the subject areas are described and mapped against the stated Program Outcomes which demonstrates that departments can share responsibility for skill and competency development across the curriculum. Successes and concerns can be identified and improvements made where necessary in time for the next courses offering.

\section{Conclusion}

It is not only students who can benefit; university faculty demonstrate more enthusiasm (and less stress) seeing their students engaged, as it shows clear indications of learning. Lasagabaster's (2011) study shows that CLIL causes improved and sustained motivation in formal learning situations. Given reallife, $21^{\text {st }}$ century tasks, understood by Gen Z, then perhaps motivation and ensuing engagement may be even higher still. Institutions themselves will also benefit. Kuh (2001) says that engaged students are a demonstration of better quality institutions. As such, learning outcomes are important for recognition.

This paper has briefly described an approach to developing course learning outcomes related to research, critical reading, writing and thinking, and teamwork skills - the desired competencies for 
participation in a knowledge based society. The focus is on designing stimulating learning environments that support knowledge and skill acquisition while engaging learners in relevant, hands-on tasks.

Perhaps the most important aspect though, is that all stakeholders see demonstrable gains in spending considerable amounts of time and money in acquiring an education. It should be an experience which is positive, challenging and engaging. Upon completion of the program of study the "principal question asked of the student or the graduate will therefore no longer be "what did you do to obtain your degree?" but rather "what can you do now that you have obtained your degree?" (Council of Europe, 2002).

\section{Further Research}

Further research into the impact of an outcomes-based approach in higher education is much needed. Well-described performance indicators of desirable student learning outcomes would highlight gains, and areas of concern, as part of a planned and ongoing review process.

Feedback, not only on attainment of outcomes, but also of student and faculty perceptions of the approach, its relevance and application to their studies, their motivation or resistance would also be of interest. Such research would undoubtedly be of use to the continuous effort to engage CLIL students in effective, collaborative, and rigorous, educationally purposeful activities.

\section{References}

Anaya, G. (1999). College Impact on Student Learning: Comparing the Use of Self-Reported Gains, Standardized Test Scores and College Grades. Research in Higher Education. 40 (5), pp 499-526.

Anderson, W. and Krathwohl, D. R. (2000). A taxonomy for learning, teaching and assessment: A revision of Bloom's taxonomy of educational objectives. White Plains, NY: Longman.

Anderson, L.W. (Ed.), Krathwohl, D.R. (Ed.), (2001). A taxonomy for learning, teaching, and assessing: A revision of Bloom's Taxonomy of Educational Objectives (Complete edition). New York: Longman.

Bean, J. P (2005) Nine Themes of College Student Retention. In Seidman, A (Ed) College Student Retention: Formula for Student Success, Washington DC: ACE \& Praeger, pp 215-244

Beckett, G. H., \& Miller, P. C. (2006). Project-based second and foreign language education: Past, present, and future. IAP.

Berlach, R. G. (2004). Outcomes-based education and the death of knowledge. Paper presented at The Australian Association for Research in Education Conference, The University of Melbourne, Victoria, Australia. Nov 28 - Dec 2, 2004. Retrieved from: http://asopa.typepad.com/files/obe-thedeath-of-knowledge.pdf

Beichner, R., Deardorff, D., \& Zhang, B. (1999). GOAL-oriented Problem Solving. Retrieved from: http://ncsu.edu/PER/Problem\%20SolvingF04.pdf

Bloom, B. S. (1956). Taxonomy of educational objectives. 1. Cognitive domain. New York: David McKay.

Bransford, J., Brown, A., \& Cocking, R. (2000). How people learn: Brain, mind, experience, and school. Washington, DC: National Academy Press.

Chickering, A. W., \& Gamson, Z. F. (1987). Seven principles for good practice in undergraduate education. AAHE bulletin, 3, 7. Retrieved from: http://files.eric.ed.gov/fulltext/ED282491.pdf

Christenson, S.L., Reschly, A. L., Wylie, C. (Eds.). 2012. Handbook of research on student engagement. New York: Springer Science + Business Media.

Council of Europe (2002), Seminar on Recognition Issues in the Bologna Process, Lisbon, April 2002. Retrieved from: http://www.coe.int 
Robert Craig

Coyle, D. (2007). Content and language integrated learning: Towards a connected research agenda for CLIL pedagogies. The International Journal of Bilingual Education and Bilingualism 10, no. 5:543 62.

Coyle, D. Hood, P. \& Marsh, D. (2010). Content and language integrated learning. Cambridge: Cambridge University Press.

Cross, K.P. (1992) Classroom assessment/classroom research: Four years into a hands-on movement. The National Teaching and Learning Forum, 1 (6), 1-3.

Dalton-Puffer, C. (2007). Discourse in content and language integrated learning (CLIL) classrooms. Philadelphia, PA: John Benjamins.

Fink, L.D. (2003). Creating significant learning experiences: An integrated approach to designing college courses. San Francisco: Jossey-Bass.

Geyer, F. (2001) Sociology of alienation. In International encyclopedia of the social and behavioural sciences, ed. N.J. Smelser and P.B. Baltes, 388 -92. Oxford: Pergamon.

Harper, S. R., \& Quaye, S. J. (2009). Beyond sameness, with engagement and outcomes for all: An introduction. In S. R. Harper \& S. J. Quaye (Eds.), Student engagement in higher education: Theoretical perspectives and practical approaches for diverse populations (pp. 1-15). New York, NY: Routledge.

Harper, S. R., \& Quaye, S. J. (Eds.) (2014). Student Engagement in Higher Education: Theoretical Perspectives and Practical Approaches for Diverse Populations. Revised Edition. New York, NY: Routledge.

Hejazi, B.M and Janzen, K. (2011). A Transformational Perspective on Quality and Mobility in Higher Education Community College Leadership Program, OISE, University of Toronto. Retrieved from: http://siddha.jfn.ac.Ik/OBESCL/MOHE/OBE-Articles/Books-chapters-n-Reports/3.OBETransformational-Perspective.pdf

Hénard, F. (2010), Learning Our Lesson: Review of Quality Teaching in Higher Education, Paris, OECD Publishing. Retrieved from: http://dx.doi.org/10.1787/9789264079281-en.

Jenkins, A. \& Unwin, D. (2001). How to write learning outcomes. Retrieved from: www.ncgia.ucsb.edu/education/curricula/giscc/units/format/outcomes.html

Jimerson, S. R., Campos, E., and Greif, J. L. (2003). Toward an understanding of definitions and measures of school engagement and related terms. California School Psychologist, 8, 7 - 27. Retrieved from: http://ed-psych.utah.edu/school-psych/_documents/grants/autism-traininggrant/CSP2003.pdf\#page $=9$

Kinkead, J. (2003). Learning through inquiry: An overview of undergraduate research. New Directions for Teaching \& Learning. Issue 93. Retrieved from: https://web.b.ebscohost.com/ehost/pdfviewer/pdfviewer?sid=d176d7e0-99ee-4ccb8f47-ffa81271ad05\%40sessionmgr114\&vid=3\&hid=121

Krathwohl, D. R. (2002). A Revision of Bloom's Taxonomy: An Overview. Theory into Practice, 41(4), 212. Retrieved from: https://search.ebscohost.com/login.aspx?direct=true\&db=tfh\&AN=8550701\&site=ehostlive\&scope=site

Kuh, G.D. (2001). The national survey of student engagement: Conceptual framework and overview of psychometric properties. Bloomington, IN: Indiana University Center for Postsecondary Research \& Planning. Retrieved from: http://nsse.indiana.edu/2004_annual_report/pdf/2004_Conceptual_Framework.pdf

Lasagabaster, D. (2011). English achievement and student motivation in CLIL and EFL. Innovation in Language Learning and Teaching, 5(1), 3- 18. Retrieved from: 
http://www.laslab.org/upload/english_achievement_and_student_motivation_in_clil_and_efl_setting s.pdf

The McCrindle Blog. Retrieved: http://blog.mccrindle.com.au/the-mccrindle-blog/page/19/

Malan, S.P.T. (2000). The 'new paradigm' of outcomes-based education in perspective. Tydskrif vir Gesinsekologie en Verbruikerswetenskappe, Vol 28, 22-28. Retrieved from: http://www.ajol.info/index.php/jfecs/article/viewFile/52788/41390

Marriam, S. B., and Caffarella, R. S. (1991) Learning in Adulthood. San Francisco: Jossey-Bass.

Nilson, L. B. (2010). Teaching at its best: A research-based resource for college instructors. John Wiley \& Sons.

Organization for Economic Cooperation and Development (OECD). (2004) Knowledge economy: Implications for knowledge and learning. Retrieved from: http://www.oecd.org/LongAbstract/0,3425,en_2649_39263294_31658285_1_1_1_1,00.html.

Purser, L. (2003). Recognition issues in the Bologna Process: conclusions and recommendations. In S. Bergan (Ed.), Recognition issues in the Bologna Process. Council of Europe. Retrieved from: https://books.google.ae/books?lr=\&id=qL0wjo33QclC\&dq=L+Purser++Recognition+Issues+in+the+ Bologna+Process\&q

Tross, S. A., Harper, J. P., Osherr, L.W., and Kneidinger, L. M (2000). Not just the usual cast of characteristics: Using personality to predict college performance and retention. Journal of College Student Development. 41 (3), pp 325-336.

Vygotsky, L. S. (1978). Mind in Society: The development of higher psychological processes. Cambridge, MA: Harvard University Press (M. Cole, V. John-Steiner, S. Scribner, \& E. Souberman, Eds. and Trans.; original works published 1930-1935).

Zhan, W. (2014) Research experience for undergraduate students and its impact on STEM education. Journal of STEM Education: Innovations \& Research. 15(1): 32-38. Retrieved from: https://search.ebscohost.com/login.aspx?direct=true\&db=a9h\&AN=96381828\&site=ehostlive\&scope=site 